\title{
The daily routine of nurses in rural areas in the Family Health Strategy
}

\author{
O cotidiano de enfermeiros em áreas rurais na estratégia saúde da família \\ El cotidiano de enfermeros en áreas rurales en la Estrategia Salud de la Familia
}

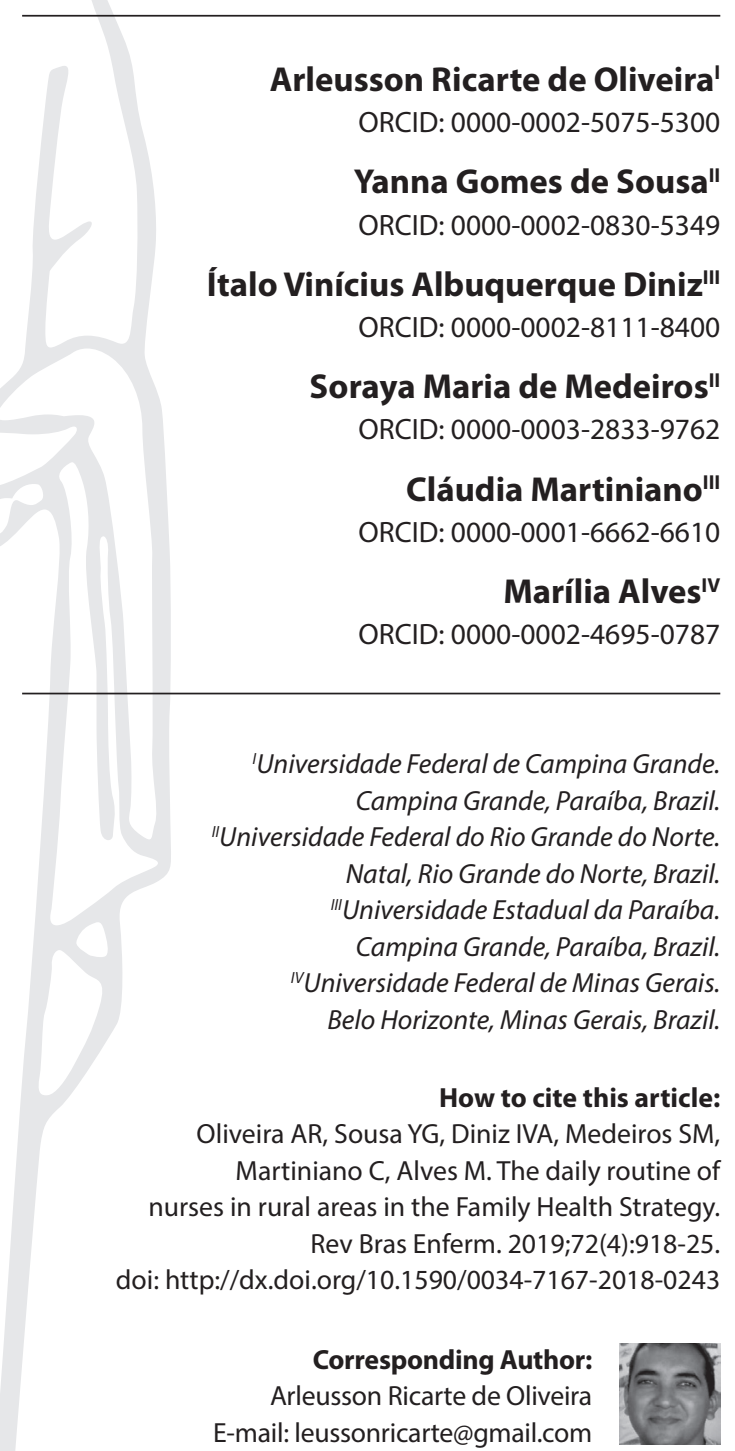

Submission: $05-08-2018$

Approval: 09-23-2018

\section{ABSTRACT}

Objective: to analyze the daily work of rural Family Health Strategy (FHS) nurses. Method: a qualitative, descriptive and exploratory research. The data were collected with eleven rural nurses of the city of Campina Grande, Paraíba State, through semistructured interviews, between January and March of 2017, using Content Analysis. Results: rural nurses have a strong relationship with the population. However, they reveal a daily work with various organizational barriers that range from the team displacement to the workplace to the operationalization of health actions, which are mediated by the characteristics of rurality. Some of these barriers can be remedied by a more proactive action from the management. Final considerations: conditioned by the characteristics of rurality, the differentiated dynamics work reveal weaknesses in the quality of nursing care and lower effectiveness of the FHS.

Descriptors: Nursing; Primary Health Care; Professional Practice; Rural Health Services; Community Health Services.

\section{RESUMO}

Objetivo: analisar o cotidiano de trabalho de enfermeiros da Estratégia Saúde da Família (ESF) que atuam em áreas rurais. Método: pesquisa qualitativa, descritiva-exploratória. Os dados foram coletados com onze enfermeiros da área rural do município de Campina Grande-PB, por meio de entrevistas semiestruturadas, entre janeiro e março de 2017, com análise a partir da técnica de Análise de Conteúdo. Resultados: os enfermeiros das áreas rurais têm relação de vínculo intensa com a população, no entanto, revelam um cotidiano de trabalho com várias barreiras organizacionais que vão desde o deslocamento da equipe ao local de trabalho à operacionalização das ações de saúde, sendo essas mediadas pelas características da ruralidade. Algumas dessas barreiras podem ser sanadas pela ação mais propositiva da gestão. Considerações finais: a dinâmica de trabalho diferenciada, condicionada pelas características próprias da ruralidade, revelam fragilidades na qualidade da assistência de enfermagem e menor efetividade da ESF.

Descritores: Enfermagem; Atenção Primária à Saúde; Prática Profissional; Serviços de Saúde Rural; Serviços de Saúde Comunitária.

\section{RESUMEN}

Objetivo: analizar el cotidiano de trabajo de enfermeros de la Estrategia Salud de la Familia (ESF) que actúan en áreas rurales. Método: investigación cualitativa, descriptivaexploratoria. Los datos fueron recolectados con once enfermeros del área rural del municipio de Campina Grande-PB, a través de entrevistas semiestructuradas, entre enero y marzo de 2017, con análisis a partir del Análisis de Contenido. Resultados: los enfermeros de las áreas rurales tienen relación de vínculo intensa con la población. Sin embargo, revelan un cotidiano de trabajo con varias barreras organizacionales que van desde el desplazamiento del equipo al lugar de trabajo a la operacionalización de las acciones de salud, siendo estas mediadas por las características de la ruralidad. Algunas de esas barreras pueden ser sanadas por la acción más propositiva de la gestión. Consideraciones finales: la dinámica de trabajo diferenciada, condicionada por las características propias de la ruralidad, revelan fragilidades en la calidad de la asistencia de enfermería y menor efectividad de la ESF.

Descriptores: Enfermería; Atención Primaria de Salud; Práctica Profesional; Servicios de Salud Rural; Servicios de Salud Comunitaria. 


\section{INTRODUCTION}

For the development of health systems, Primary Health Care (PHC) is based on strengthening access and universal health coverage, which are priorities for improving global health ${ }^{(1)}$.

Internationally, remote and rural areas are the places where there is greater difficulty in covering health services, with poorer health outcomes, especially related to maternal and infant mortality, infectious diseases, and aging ${ }^{(2)}$. Other difficulties are also observed, such as maintenance of health professionals in these areas, unequal distribution and high turnover of these workers, especially physicians ${ }^{(3)}$.

The Working Party on Rural Practice (WONCA) highlights the necessary aspects of rural health care in order to achieve the Rural Healthy People 2020's goal: rural context, rural health status, rural health care services, rural health human resources, rural health care research, rural health financing, rural health care organization, rural health consumer satisfaction, among others. Therefore, high-quality and effective health care is required, which requires effort and organization in most countries around the world compared to urban standards ${ }^{(4)}$.

In Brazil, the major challenge facing the health sector is the implementation of quality $\mathrm{PHC}$ in a country with many socioeconomic differences and inequalities in access to health services. Challenges still include low numbers of health professionals, especially physicians with adequate qualifications to offer universal coverage in the various regions of the country. Another problem is that the coordination of the attention between the sectors of PHC and the specialized attention takes place in the long term, and in a country that presents/displays rapid aging population. In rural and remote areas, the problem is more aggravating as they are more sensitive to sociocultural problems $s^{(5)}$.

The Declaração de Brasília (Brasília Declaration), a document proposed by the Rural Medicine Working Group (WG) of the Brazilian Society of Family and Community Medicine (SBMFC - Sociedade Brasileira de Medicina de Familia e Comunidade) points out that the rural area has varied characteristics regarding health indicators, the practice of health professionals, the characteristics of the system and the territory-process, involving the dynamics of each area or region. Rural populations generally have worse health and social determinants than urban ones, as well as more frequent health problems. Another aspect is the rate of preventive coverage and self-assessment of health that are also worse in rural areas, taking into account the differentiated profile of this population ${ }^{(6)}$.

The Family Health Strategy (FHS) was instituted in Brazil by the Ministry of Health in 1994, and it is considered a priority strategy for the structuring of $\mathrm{PHC}^{(7)}$. It is guided by the principles of accessibility, longitudinality, coordination, comprehensiveness, cultural competence, family and community orientation ${ }^{(8)}$.

The FHS nurse develops multiple educational, care, and administrative activities. He contributes to the resolving of the different levels of health care of the population, and his role has become relevant for the expansion and consolidation of this strategy in the reorganization of the healthcare model in Brazil(9).

Nonetheless, the way of working in the FHS has contributed to nurses' overload, especially work overload, excessive demand, units' infrastructure deficit and care network failures. This hampers its effectiveness as a privileged strategy to achieve universal access in health. On the other hand, team work, affinity with work, link with user, and resolvability of the assistance contributed to its reduction ${ }^{(10)}$. Challenges become greater when this professional is inserted in realities with specific contexts for the development of their practices.

In Brazil, there is no specific $\mathrm{PHC}$ policy for rural areas. Although there is a Política Nacional de Saúde Integral das Populações do Campo e das Florestas (freely translated as Brazilian Comprehensive Field Populations Health and Forests' Health Policy) ${ }^{(11)}$, translating for practice, this policy is not articulated with the country's National PHC Policy. Currently, the policy that regulates PHC in Brazil is Ordinance GM 2436/2017(12), which is applied to both urban and rural areas.

Regarding the practice of professionals in health services, rural health professional usually acts in situations of relative "isolation" or with smaller teams and few resources, although the health worker's relationship with the communities is closer. Different skills and competencies of professionals are needed to deal with typically rural health situations, and broaden the skills to deal comprehensively, socially and family with people ${ }^{(6)}$.

The daily work approach, for rural FHS nurses, implies making explicit facts and actions of the daily life that require reflection and creation, especially for the diversity of actions developed. This professional deals with situations in their professional practice that facilitate and often limit the continuity of care. Considering that there are still few studies in the international and national setting that relate nurses' work to the rural context, we intend to answer the following questions: how is the daily routine of nurses working in rural areas of the FHS configured? What is the nurse's view of the conditions under which he performs his work?

\section{OBJECTIVE}

This study aims to analyze the daily work of rural FHS nurses.

\section{METHOD}

\section{Ethical aspects}

This study is part of the doctoral thesis entitled"Os sentidos do trabalhoparaenfermeiros no cotidiano da Estratégia Saúde da Família urbana e rural" and followed the norms of the Brazilian Health Board - CNS (Conselhonacionalde Saúde) Resolution 466/12, with approval by the Research Ethics Committee of the Universidade Federal de Minas Gerais.

\section{Type of study}

This is a qualitative study, whose data were analyzed through Content Analysis ${ }^{(13)}$, carried out in the FHS of rural areas of Campina Grande, Paraíba state.

\section{Methodological procedures}

\section{Study setting}

The study setting was rural health units with FHS of a large municipality. The municipality has 10 rural Family Health Units (FHU), where 11 Family Health Teams (FHT) are allocated. Initially, a telephone contact was made with the Health Districts 
The daily routine of nurses in rural areas in the Family Health Strategy Oliveira AR, Sousa YG, Diniz IVA, Medeiros SM, Martiniano C, Alves M.

Coordinators of Campina Grande to explain the purpose of the study and to request a schedule with the nurses to present the research project and plan the beginning of the interviews.

\section{Fonte de dados}

The inclusion criteria of the study subjects were to be a FHS nurse of Campina Grande-PB and to work in a exclusively rural area for at least 06 (six) months; belong to the effective or hired professionals staff of the municipality. The exclusion criteria were to be away from work during data collection period; be on health leave or on vacation. All the nurses of the municipality who worked in the rural area were included. The 11 nurses invited to participate in the study met the inclusion criteria.

\section{Collection and organization of data}

Data collection took place between January and March 2017, through a semi-structured interview. It had a script built from a literature review, with aspects related to the daily work of nurses. Individual interviews were carried out in the participants' work units, as scheduled, recorded and transcribed in full after signing the Free and Informed Consent Term (FICT). The duration of each interview was approximately 30 minutes. To preserve the anonymity of the participants, they were identified by the letter E next to a sequential number (E1 to E11), following the order of the interviews.

\section{Data analysis}

The reports were transcribed, organized and submitted to Content Analysis, following the three steps: pre-analysis, in which the "floating" (quick) reading of the statements was carried out, followed by the exhaustive reading of the material when the registration units were selected, forming a cut of the reports for later organization. In the third step, recording units were organized into categories ${ }^{(13)}$ and interpreted according to the literature.

The results were organized into four categories: Displacement to rural area: route and mishaps; Work schedule and (im)possibility of access guarantee; Nursing care practices in rural areas; and Working conditions mediated by the dynamics of rurality.

\section{RESULTS}

The health professionals interviewed were eleven rural nurses from the FHT of Campina Grande-PB, aged between 30 and 50 years (90\%), predominantly female (91\%), living in Campina Grande city (73\%). There was a predominance of professionals with complete graduate degree (91\%). Of these, $21 \%$ of the professionals had Master's degrees and 79\% had specialization. The FHS's duration in the rural area ranged from one to six years (36\%) and seven to twelve years (45\%). $82 \%$ of work regime was statutory.

\section{Displacement to rural area: route and mishaps}

Rural nurses, even before beginning their daily work, perceive their routine modified according to the same, since they have to deal with domestic tasks before the beginning of the route to rural area:
I wake up every day from five thirty in the morning, because I have to do things still at home, in the sense of preparing breakfast. [...] / walk every day [...] then when I arrive, I prepare my breakfast. [...] / organize things to be able to wait for the driver, since I work in rural areas. (E4)

I wake up early, I leave more or less my lunch ready. I do not have a secretary, so I do half at night and in the morning I finish it, I get dressed, and wait for the driver. (E9)

FSH nurses' work path is differentiated by becoming a long route, with a dynamic that goes beyond the work-to-work displacement, since a single transport is used for all the team, characterizing a new displacement arrangement.

The Department of Health's driver picks us up at home after seven-thirty, because he's picking up other people. Then, when he arrives to my house, it's almost eight o'clock, because I'm almost the last one. (E1)

The car leaves the Department at seven o'clock in the morning. As I live closest to the Department, then I am the first to be picked up around seven fifteen. [...] on the way back home, the same thing happens, the car leaving everyone and I'm the last to be left at home. Every day is an hour to come and an hour to go back. (E2)

By following the route to the rural area, nurses are faced with situations to be solved in order to enable health assistance in rural units.

[... ] then, when we go out, we make the necessary routes to get to the unit. Almost every day, we have to go to the Department. To get a vaccine the day before, we leave the box in the immunization room [...].We have to take the exams to the Department, so that the other day or when they say they have a mark, we have to go there to get it. In the urban zone, you do not need to get stressed. (E8)

[...] These anchor health centers are not $100 \%$ equipped, so that we cannot get there and be served. We are obliged every day to go to the headquarters to get the materials. (E4)

\section{Work schedule and (im)possibility of access guarantee}

In the rural area, nurses deal with a unique work schedule, considering the specific characteristics present in the configuration of the territory in which the population is dispersed. In this way, the work shifts are divided to assist people residing in several micro areas, which requires, from this professional, specific skills to deal with the different needs of the population.

We have two anchors, the anchor of [unit name], it is where it has a larger population, and the demand is greater. We meet twice a week there on Tuesdays and Thursdays. Here, in [unit name], we serve every Monday and Wednesday, fortnightly. And [unit name] that is another anchor; we serve every fifteen days. (E7)

[...] it is not our reality that of being every day in the same place... [...] I realize that we could give a better assistance, but it's very hard. If we had a longer time, we would give more assistance... [...] we realize that you have this difficulty because you only go once a week [...] when you have a holiday, it's sad. It's a lot of people for so little time. (E10) 
In this study, the nurses' working days' periodicity in the area covered by the team varied from one to two times a week and in the same locality, or even once or twice a month. He has to divide the working time in the rural area for care in units located in different places of the territory.

\section{Nursing care practices in rural areas}

In the reports, it is identified that the actions performed in the health units are very similar, and with service to groups already known by the ministerial protocols. The nurse sees himself with little schedules to develop his daily practices, often occurring the spraying of his actions. Thus, the way of organizing these practices seems to follow the model of programmatic actions and individual service of spontaneous demand.

[...] it's different from working in the countryside, every day we're in a different place. [...] we go one day to each place in the countryside, then you end up serving everyone together. [...] this is a differential point in relation to the urban zone that we can organize the schedule better. (E6)

[...] we have some landless settlements [...] and it's a little distant from one place to another, then you have to make those home visits to the bedridden... (E7)

Although nurses have short periods of time to assist the population, since the work happens in several units and is sparse in the territory, the relation of bond with the population potentiates the development of daily practices. In addition to the individual visits during the nursing visit and the activities of home visits of this professional to the families, there are group meetings on the commemorative dates that favor the relation of the nurse and the FHT to promote the health care for the population.

[...] we create bonds with the community... [...] they have such great trust and credibility that it ends up looking for us and we meet that community longing, [...] we answer as much as possible. (E4)

[...] there are the activities of the groups, there in the festive months, São João, there we do a 'quadrilha' (Quadrilha is a typical dance of "Festa Junina", also known as the festa de São João for their part in celebrating the nativity of St. John the Baptist [(June 24), are the annual Brazilian celebrations adapted from European Midsummer that take place in the southern midwinter]. It's exciting... [...] Then we dance, the team dances too. It has a "quadrilha" with the elderly. And at Christmas, we also get together with them, and they like it very much. (E5)

Nurses feel satisfied with teamwork, identify with work in rural areas and contribute to improved health of the population:

I have worked in many places all my life, I have always liked the rural areas, riding motorbikes with the $\mathrm{CHA}$, in the rain, in the sun, passing inside a pond, passing over stone and... [...] see the improvement.. [...] I take health, this is very good. (E9)

We have almost no deaths here. We do not have a child's death, we follow the children from zero to two years, every month. I think that for the health-disease process, we really contributed. (E8)

\section{Working conditions mediated by the dynamics of rurality}

Dissatisfaction with the working conditions was reported by all the participants and negatively impacts the development of the daily practices of the professionals. In relation to transport, in addition to the daily life risks that nurses face when traveling to rural areas, on asphalt and ground roads, testimonies reveal that transportation does not present good conditions.

[...] for us to go from here to the anchors, is already a little more complicated because it is ground road... (E7)

[...] and we risk everyday our lives to be in a BR road ... [...] and a car of the Department that has no maintenance. [...] We have already been broken at BR road, without fuel. (E10)

Some reports also point out deficiencies in the units' infrastructure, as well as the unavailability of drugs, materials and equipment for work.

[...] because they are four health centers, but only have a device to check pressure, only have a meter, only has an anthropometric rule that is to do the child care of children and only has a sonar. So that's why we have to take it wherever we go. (E4)

[...] it's frustrating when you try to do some things, some actions and no success, lack of structure, lack of material. Anyway, in that sense, it's a little frustrating. (E6)

Another obstacle encountered by the interviewees was the lack of water in the rural units to carry out the procedures. Due to the problem of drought in the region, the supply of most rural units occurs through tank wagons, and in an irregular way, which hinders the nursing procedures, such as the collection of cytological material, dressing, administration of vaccines, among others.

[...] it happens to have no water in the unit ... [...] is another big hindrance. The worst thing is that we have to stop cytology, stop vaccination [...] we do this ... what can, right? [...] but there it is, there is that incomplete care. (E5)

[...] when I got here, there was no water, because there is no piped water, water that comes from the tank wagon, and there was a cistern, but there was no pump to pull the water. (E8)

Another aspect evidenced, in the majority of the testimonies, was the unavailability of lunch for professionals. Of the three rural districts in the municipality, only respondents from one of the districts (which is located in the rural area farthest from the city) reported availability of lunch at the rural units for professionals. This problem causes them to be unable to extend the working time on the unit.

[...] since November lunch is not being offered to us. So we have to do everything until noon... [...] is really hurry, we did not decrease the scheduled appointments, we continue, so it is rushed to account. Before lunch came, because the time was until 03:00 pm, then we would close the unit from 12:00 until 12:40 for lunch and then open and stay until 03:00 pm. (E2) 
[...] we do not have lunch, we bring lunch from home and that's why we're running on time. Then we meet the demand that has to meet and then we go home in Campina Grande, to have lunch there. (E4)

\section{DISCUSSION}

The study on the daily work of nurses in rural areas in the FHS revealed a differentiated work dynamics for these professionals, conditioned by the characteristics of rurality. With regard to women's work, it was found in the results of this study that women are the protagonists of domestic work and caring for the home. This overlapping of various internal and external roles and pressure directly affects the quality of life of these nurses, as well as the process of caring for and educating their own children. In this respect, it is necessary to recognize the limits inherent in the human being, in order to guarantee to these working women, the conduct of their personal and professional lives without any harm to their physical and mental well-being ${ }^{(14)}$.

In this study, the daily displacement of nurses to rural areas was verified. This is a reminder of the international context, given that data from the World Health Organization show that half of the world's population lives in rural and remote areas. In contrast, most health professionals live and work in urban areas ${ }^{(15)}$.

The time spent on the displacement of nurses in this study interferes with the feasibility of assistance in rural areas. In addition to geographical barriers due to the distance between localities, these professionals are faced with administrative work situations to be solved during the course, and that influence the time of beginning the service to the population when arriving at the rural locality. The short time the health worker stays in rural areas may interfere with the quality of care.

This situation could be minimized by the management by guaranteeing the logistical contribution for maintenance and supply of the rural FHU, with guarantee of the supply of inputs, materials and equipment necessary for the professionals' work and better conditions of displacement. In this way, it would be possible to optimize the travel time for the rural area, in addition to reducing the overload of nurses who, in their daily lives, already take on administrative and care tasks.

Regarding work schedule, it was evidenced that, due to the differentiated organization of the work process in the rural area, the nurses perform the programming of care according to the geographical location and the distribution of the health units in the rural area, which are, in the majority, distant from each other. Therefore, it is common for professionals to find difficulties in performing care, with a view to reducing service shifts by location, generating care gaps, and compromising the comprehensiveness of health care. Some studies show that there is little possibility of a change in care model in rural areas, where access to basic health services is low, with a high population that seeks specialized and hospital care ${ }^{(16-18)}$.

Considering the accessibility of the service, a study evaluated the satisfaction of FHS users in the rural area of two small municipalities of Rio Grande do Norte, which revealed as a negative point the daily non-permanence of professionals in the units of their localities $^{(17)}$. Another research carried out in the rural area of the city of Prudentópolis, Paraná State, showed that health professionals worked in a fragmented way, serving more than one locality in a short space of time, which influenced the quality of care ${ }^{(16)}$.

It is important to emphasize that the Constitution guarantees the right to health for both urban and rural populations, and the specific ways of life of these populations must be considered. Nevertheless, the rural population experiences health inequities, with differentiation in the organization and provision of health services. Completeness in the Brazilian Unified Health System (SUS) is based on the idea that the population should be served according to their needs, and that health institutions should be structured in such a way as to guarantee comprehensive health care ${ }^{(19)}$.

The changes that have taken place in recent years in public policies in Brazil have opened the way for the valorization of actions in rural areas. Land conflicts, social security rights, recognition of specific rural populations that were little known, such as the landless, people affected by dams, small farmers, fishermen, quilombola communities (A quilombola is an AfroBrazilian resident of quilombo settlements first established by escaped slaves in Brazil), indigenous peoples, riverine people, among others, intensified ${ }^{(20)}$.

The new rurality must be understood, considering the transformations that the rural area has been gaining, of a place as dwelling space, of social, economic, political and cultural life. A more meaningful rural was thought, that gradually ceased to be seen as residual and discussed as politics, considering the needs of improving the conditions of those who live in the place, and with traditional ways of life and organization. Therefore, the dynamics of the creation of laws cannot be distant from social reality ${ }^{(20)}$.

Regarding the daily practices of professionals, the results showed a predominance of curative care practices on health promotion actions. In this regard, a study conducted with 38 FHS professionals from different categories on the FHT working process of Campina Grande-PB revealed barriers in the health care of users, with attendances signed by mechanical acts, devaluation of listening for greater understanding health needs. Another aspect revealed was that the service is organized around a fixed schedule $^{(21)}$. However, health actions should be guided by the specificities of the contexts of the territories that determine and adjust practices appropriate to these singularities. This ensures greater approximation with the social production of collective health problems in the various places where daily life happens ${ }^{(22)}$.

The relationship between the nurse and the rural population is related to health problems, and this relationship favors the development of health practices by the professional. The rural population, because they live far from the city, have health professionals, often, as the only alternative to respond to their problems. In addition, it is not common the existence of social facilities in rural areas. There is also a particular aspect in this relation of the people of the rural area with the professionals of health and vice versa. The nurse, entering families' homes and having good acceptance, becomes part of the intimacy of the people, which makes it possible to broaden the approach to existing needs and share responsibilities in care and citizenship.

Considering that the rural population is diversified by characteristics that include cultural, racial and regional specificities, among others, it is important that the nurses consider these singularities to act effectively in health promotion and protection ${ }^{(23)}$. For this, the 
creation of professional-user link is necessary to think of strategies of clarification and education ${ }^{(24)}$. Community-centered care with cultural competence should be the principle of all health policies ${ }^{(25)}$.

In addition to the link, other potential aspects of nurses' work were teamwork and identification with work in rural areas. Interdisciplinary work presumes the establishment of interpersonal relations based on collaboration and communication, with the purpose of contributing to the development of a work that is based on the construction of dialogical and horizontalized relations. In this sense, it is possible to implement an assistance that is committed to the needs of the population ${ }^{(26)}$. Regarding identification with work in rural areas, although there are difficulties for nurses to perform, it is possible to construct a creative and supportive practice in order to develop new paths for nursing care that favors qualified listening and quality improvement life in rural areas.

It is also important to highlight the relevant role of the nurse in improving the population's health, in relation to the approach with user and family. It contributes to the understanding of the social, emotional and family context, as well as the consolidation of this work, seen as socially important, in the sense of making possible modifications in the community in which it develops ${ }^{(27)}$.

Regarding the working conditions, the results pointed to the dominance of situations that generate work overload of the nurses. Among the contributing factors are related to the poor ability of FHT work management in rural areas. However, the Gramado Statement for Rural Health in developing countries recommendations are that rural health professionals should be valued in several aspects, such as training, policies to encourage students from rural areas, improvement in the quality of work, life and financial, including the inclusion of career programs ${ }^{(25)}$.

Nurses, at times during their work performance, tend to accept certain risk situations as inherent in the profession. They often undergo inhuman conditions, lack of human and material resources, work overload, conflicting interpersonal/professional relationships, among other conditions that put them in the face of various situations of risk, vulnerability and disability ${ }^{(28)}$.

A study carried out with nurses from a municipality in the interior of the Northeast, about the precariousness of work at FHT, also corroborates with the findings of the present study. Interviewees cited weaknesses related to the lack of basic equipment and materials in the units, disfavoring care of the health team $^{(29)}$. These aspects constitute impasses for nurses to perform their functions, which generates feelings of anguish and frustration, for not being able to fulfill their activities.

It should also be noted that the rural population, in the settings studied, already lives with the problem of lack of water in their daily lives. The rural population of the Northeast, long in its history in rural areas, has been the biggest drought victim. It was six years of one of the most intense periods of drought that caused damages to the northeastern fields beyond vegetation and gazing deaths. Many sites were abandoned, and houses and grocery stores were closed. In addition to the drought, the wave of insecurity also reached the countryside, instilling fear in the population. The increase in violence ended the typical ritual of the backcountry: the round of conversations in the porches at the end of the day, when farmer and pawn, bosses and employees were reunited with the family ${ }^{(30)}$.
It is possible to infer that attempts to solve the problems and to implement the principles and guidelines recommended by the FHS stand in the way of a lack of material conditions to make social life viable (water, housing, roads, telephony, transport, health care). It also includes the difficulty of overcoming a reified attitude of submission, and dependence, which renders individual and natural health problems ${ }^{(18)}$.

Testimonies reveal difficulties in the service caused by organizational barriers, weakening the continuity of care by nurses who, on the one hand, know the user's need, but, on the other, find difficulties to carry out their work. These aspects trigger a feeling of impotence because they cannot visualize the fullness of their work, which can trigger the loss of meaning for the work they perform.

In order to reduce inequities in rural health and to strengthen the comprehensiveness of health care, it is necessary to develop strategies to deal with daily problems in health services, which suppress some aspects: insufficiency of human resources in health teams, geographical difficulties, unavailability of medications, difficulty in marking exams and coordination of care in the health care network ${ }^{(31)}$.

It is important to emphasize that improving working conditions can reduce the exposure to attrition at work, having more satisfied nurses with fewer licenses and shortages, improving the quality of care provided. Rethinking the organizational structure of rural FHT, with a view to ensuring functionality and integrating the worker who is effectively confronted daily with work overload, should be the focal point of interventionist proposals of managers for these services.

\section{Study limitations}

This study presents the limitation of having been carried out in a specific rural area, not being possible its generalization, due to the diversity of ruralities in Brazil.

\section{Contributions to nursing}

The research reveals the importance of universities in the training of nurses, in the implementation of their course plans, specific contents that take into account the work of rural FHS, as a way to awaken in students the importance of the specificity of work in rural areas. It also highlights the local manager's role in the feasibility of the work carried out by the team that provides assistance in rural areas.

\section{FINAL CONSIDERATIONS}

Over the years, PHC has been considered the network's coordinator and care coordinator, which is fundamental in a health system that aims to improve care for the population. In this context, nurses' performance in rural FHS has been relevant, contributing to the improvement of health levels of the population. Nonetheless, nurses working in rural areas face difficulties related to transportation to the rural area, work schedule to meet the different groupings and working conditions.

In the daily work, the nurse is faced with the peculiarities of the rural area, such as the different territories and different 
health-disease processes of the population with health problems, specific to the rural environment. These characteristics require strategies implementation to address the recurrent problems in health services in rural areas that make it difficult to provide comprehensive care and access to health actions to rural users due to scarce resources and cultural aspects of the population in relation to health and disease.
There is a need for investment that guarantees adequate working conditions for nurses, as well as Permanent Education of these professionals as a way to instrumentalize work in rural areas of the FHP, with a view to guaranteeing universality, completeness and equity. Creation of new studies is suggested on the daily work of nurses in different areas, considering the country's territorial extension and different forms of FHS organization in the municipalities.

\section{REFERENCES}

1. Organização Pan-americana de Saúde. Organização Mundial de Saúde. Relatório sobre Acesso Universal à Saúde e Cobertura Universal de Saúde: cúpula de enfermeiros de prática avançada [Internet]. 2015 [cited 2018 Mar 05]. Available from: http://www.paho.org/hq/index. php?option=com_docman\&task=doc_download\&ltemid=270\&gid $=40042 \& l a n g=e n$

2. Bryant-Lukosius D, Valaitis R, Martin-Misener R, Donald F, Peña LM, Brousseau L. Advanced Practice Nursing: a strategy for achieving universal health coverage and universal access to health. Rev Latino-Am Enfermagem [Internet]. 2017 [cited 2018 Mar 05];25:e2826. Available from: http://www.scielo.br/pdf/rlae/v25/0104-1169-rlae-25-02826.pdf

3. Portela GZ, Fehn AC, Ungerer RLS, Poz MRD. Human resources for health: global crisis and international cooperation. Ciênc Saúde Coletiva [Internet]. 2017 [cited 2018 Mar 17];22(7):2237-46. Available from: http://www.scielo.br/pdf/csc/v22n7/en_1413-8123-csc-22-07-2237.pdf

4. Wonca Working Party on Rural Practice. Policy on Rural Practice and Rural Health, Monash University School of Rural Health; Traralgon, Vic. 2001

5. Stein AT, Ferri CP. Inovação e avanços em atenção primária no Brasil: novos desafios. Rev Bras Med Fam Comun [Internet]. 2017 [cited 2018 Jan 15];12(39):1-4. Available from: https://www.rbmfc.org.br/rbmfc/article/view/1586/864

6. Ando NM, Targa LV, Almeida A, Silva DHS, Barros EF, Schwalm FD, et al. Declaration of Brasília "The concept of rural and the health care". Rev Bras Med Fam Comun [Internet]. 2011 [cited 2018 Jan 13];6(19):142-4. Available from: https://www.rbmfc.org.br/rbmfc/ article/view/390/317

7. Ministério da Saúde (BR). Política Nacional de Atenção Básica. Legislação em Saúde[Internet]. 2012 [cited 2018 Feb 17]. Available from: http://189.28.128.100/dab/docs/publicacoes/geral/pnab.pdf

8. Starfield B. Atenção primária: equilíbrio entre necessidades de saúde, serviços e tecnologia. Brasília: UNESCO, Ministério da Saúde; 2002.

9. Caçador BS, Brito MJM, Moreira DA, Rezende LC, Vilela GS. Being a nurse in the family health strategy programme: challenges and possibilities. Rev Min Enferm [Internet]. 2015 [cited 2018 Feb 14];19(3):620-26. Available from: http://www.reme.org.br/artigo/detalhes/1027

10. Pires DEP, Machado RR, Soratto J, Scherer MA, Gonçalves ASR, Trindade LL. Nursing workloads in family health: implications for universal access. Rev Latino-Am Enfermagem [Internet]. 2016 [cited 2018 Feb 02];24:e2677. Available from: http://www.scielo.br/pdf/rlae/v24/01041169-rlae-0992-2682.pdf

11. Ministério da Saúde (BR). Política Nacional de Saúde Integral das Populações do Campo e da Floresta. [Internet]. Brasília; 2013 [cited 2018 Jan 17]. Available from: http://bvsms.saude.gov.br/bvs/publicacoes/politica_nacional_saude_populacoes_campo.pdf

12. Ministério da Saúde (BR). Portaria n².436, de 21 de setembro de 2017. Aprova a Política Nacional de Atenção Básica, estabelecendo a revisão de diretrizes para a organização da Atenção Básica, no âmbito do Sistema Único de Saúde (SUS). [Internet]. Brasília; 2017 [cited 2018 Jan 10]. Available from: http://www.brasilsus.com.br/images/portarias/setembro2017/dia22/portaria2436.pdf

13. Bardin L. Análise de conteúdo. São Paulo: Edições 70; 2011.

14. Rodrigues BC, Lima MF, Maschio Neto B, Oliveira GL, Corrêa ACP, Higarashi IH. Being a mother and a nurse: issues about gender and overlapping social roles. Rev Rene [Internet]. 2017 [cited 2018 Feb 20];18(1):91-8. Available from: http://www.periodicos.ufc.br/rene/article/ view/19217/29934

15. Carvalho VKS, Marques CP, Silva EN. Mais Médicos (More Doctors) Program: its contribution in view of WHO recommendations for provision of doctors. Ciênc Saúde Coletiva[Internet]. 2016 [cited 2018 Mar 5];21(9):2773-84. Available from: http://www.scielo.br/pdf/csc/v21n9/ en_1413-8123-csc-21-09-2773.pdf

16. Pitilin EB, Lentsck MH. Primary Health Care from the perception of women living in a rural area. Rev Esc Enferm USP [Internet]. 2015 [cited 2018 Feb 02];49(5):725-31. Available from: https://www.revistas.usp.br/reeusp/article/view/106676/105291

17. Uchoa AC, Souza EL, Spinelli AFS, Medeiros RG, Peixoto DCS, Silva RAR, et al. Avaliação da satisfação do usuário do Programa de Saúde da Família na zona rural de dois pequenos municípios do Rio Grande do Norte. Physis [Internet]. 2011 [cited 2017 May 29];21(3):1061-76. Available from: http://www.scielo.br/pdf/physis/v21n3/16.pdf

18. Oliveira EM, Felipe EA, Santana HS, Rocha IH, Magnabosco P, Figueiredo MAC. Socio-historical determinants of care in the Family Health Strategy: a user perspective in the rural area. Saúde Soc [Internet]. 2015 [cited 2018 Mar 17];24(3):901-13. Available from: http://www.scielo. br/pdf/sausoc/v24n3/0104-1290-sausoc-24-03-00901.pdf

19. Brasil. Constituição (1988). Constituição da República Federativa do Brasil. Brasília, DF: Senado Federal; 1988.

20. Medeiros LSM, Quintans MTDQ, Zimmermann SA. Rural and urban spaces in Brazil: legal frameworks and political strategies. 
Contemporânea, Dossiê - O mundo rural no século XXI. [Internet]. 2014[cited 2018 Mar 02];4(1):117-142. Available from: http://www. contemporanea.ufscar.br/index.php/contemporanea/article/view/195/99

21. Brandão GCG, Oliveira MAC. The embracement in the Family Health Strategy teams work process in Campina Grande-PB, Brazil. Atlas de Investigação Qualitativa em Ciências Sociais [Internet]. 2014 [cited 2017 Dec 10];3:236-240. Available from: http://proceedings.ciaiq.org/ index.php/CIAIQ/article/view/477/473

22. Monken M, Barcellos C. Health surveillance and territory: theoretical and methodological possibilities. Cad Saúde Pública [Internet]. 2005 [cited 2018 Feb 02];21(3):898-906. Available from: http://www.scielo.br/pdf/csp/v21n3/24.pdf

23. Ministério da Saude (BR). Programa nacional de saneamento rural. Brasília: MS; 2012.

24. Penna CMM, Faria RSRF, Rezende GP. Welcoming services: triage or strategy for universal health access?. Rev Min Enferm[Internet]. 2014 [cited 2017 Aug 22];18(4):823-9. Available from: http://www.reme.org.br/artigo/detalhes/965

25. Targa LV, Wynn-Jones J, Howe A, Anderson MIP, Lopes JMC, Lermen Jr N, et al. Gramado Statement for Rural Health in developing countries. Rev Bras Med Fam Comun [Internet]. 2014 [cited 2018 Feb 18];9(32):292-94. Available from: https://rbmfc.org.br/rbmfc/article/view/982/644

26. Peruzzo HE, Bega AG, Lopes APAT, Haddad MCFL, Peres AM, Marcon SS. Os desafios de se trabalhar em equipe na estratégia saúde da família. Esc Anna Nery. 2018;22(4):e20170372. doi: 10.1590/2177-9465-ean-2017-0372

27. Kessler M, Lima SBS, Weiller TH, Lopes LFD, Ferraz L, Thumé E. Longitudinality in Primary Health Care: a comparison between care models. Rev Bras Enferm. 2018;71(3):1063-71. doi: 10.1590/0034-7167-2017-0014

28. Girondi JBR, Backes MTS, Argenta MI, Meirelles BHS, Santos SMA. Thinking about the concepts of risk, vulnerability and disability with a group of nurses. Rev Eletr Enf [Internet]. 2010 [cited 2018 Feb 20];12(1):20-7. Available from: https://www.fen.ufg.br/fen_revista/v12/n1/pdf/ v12n1a03.pdf

29. Goes PS, Medeiros SM, Sousa YG, Chaves AEP, Oliveira ADS, Ferreira DR, et al. Work Precariousness In Family Health Strategy. Int Arch Med [Internet]. 2016 [cited 2018 Jan 02];9(273):1-9. Available from: http://imed.pub/ojs/index.php/iam/article/view/1680/1848

30. Cavalcanti R. Êxodo rural. Correio da Paraíba [Internet]. 2017 Jul [cited 2018 Feb 27]. Available from: https://correiodaparaiba.com.br/ colunas/exodo-rural/.

31. Pereira LL, Pacheco L. The challenges faced by the More Doctors Program in providing and ensuring comprehensive health care in rural areas in the Amazon region, Brazil. Interface (Botucatu) [Internet]. 2017 [cited 2018 Jan 10];21(Supl.1):1181-92. Available from: http://www. scielo.br/pdf/icse/v21s1/en_1807-5762-icse-21-s1-1181.pdf 